\title{
Experiences and outcomes of preschool physical education: an analysis of developmental discourses in Scottish curricular documentation
}

This paper provides an analysis of developmental discourses underpinning preschool physical education in Scotland's Curriculum for Excellence. Implementing a poststructural perspective, I examine the preschool experiences and outcomes related to physical education, as presented in the Curriculum for Excellence 'health and wellbeing' documentation. I interrogate the ways in which developmental discourses are evident throughout this and related documentation and how these discourses might 'work' to produce specific effects on practitioners and children as they are deployed and taken up in Scottish preschool education contexts. This analysis involves speculating about potential consequences for practitioners' and children's experiences and subjectivities. In conclusion, I suggest that practitioners should critically engage with the curriculum, as uncritical acceptance of the discourses underpinning it could lead to practices that may have negative consequences. Furthermore, I propose that future research should investigate the ways in which the discourses privileged in the Curriculum for Excellence 'health and wellbeing' documentation are taken up and negotiated in Scottish preschool settings.

\section{Introduction}

This paper investigates and problematises developmental discourses associated with preschool physical education in Scotland's Curriculum for Excellence (Learning and Teaching Scotland (LTS), 2009a). Implementing a poststructural perspective, I aim to identify the developmental 'truths' that underpin the preschool physical education experiences and outcomes, as presented in the Curriculum for Excellence documentation. This analysis involves examining the language that frames what is expected of preschool practitioners and children in relation to physical education. I align with Rønholt's (2002) assertion that critically interrogating discourses 'makes visible what is usually hidden' (p. 34) and thus stimulates debates around their potential implications and effects in practice. Consequently, my analysis involves raising critical questions about how the developmental discourses identified may impact on practitioners' and children's practices and subjectivities as they are taken up in 
preschool contexts. Although a significant body of research concerned with problematising the dominance of developmental discourses in early childhood education has emerged over the past two decades (Cannella, 2008), these discourses have retained a position of dominance because developmental psychology has been normalised and taken for granted in the early childhood field (Fleer, 2005). Interrogating taken-forgranted assumptions and practices is crucial so that researchers, policy-makers and practitioners can critically reflect on the potential workings of particular discourses, and strive to create positive and inclusive preschool physical education experiences. As such, I hope that this paper may encourage the development of 'new possibilities for practice' (Wright, 2006, p. 60) within Scottish preschool physical education.

\section{Background}

While a previous paper (McEvilly et al., in press) has investigated the physical education discourses more generally throughout the Curriculum for Excellence documentation, the current paper extends this work by specifically focusing on the developmental discourses underpinning the preschool physical education guidelines. McEvilly et al. (in press) report that discourses related to physical activity and health are particularly prominent throughout the physical education sections of Curriculum for Excellence, along with a related concern with motor skill development. The current paper shows that these discourses also underpin the sections of the curriculum that specifically pertain to preschool physical education, though I do not focus on the physical activity and health discourses.

Preschool physical education has been largely unexplored by researchers. While an increasing body of literature is concerned with preschool physical activity, little is known about preschool physical education, by which I mean planned, structured 
physical learning experiences in curricular time. This may be because most physical education research focuses on the secondary school domain (Kirk, 2005), or because early childhood curricular frameworks tend to be structured according to areas of development, rather than specific subjects (Stephen, 2006). Of significance to the current paper, however, is that Curriculum for Excellence specifically refers to 'physical education' in relation to preschool education (see LTS, 2009c); the previous Scottish preschool curriculum - A Curriculum Framework for Children 3-5 (LTS, 2004) - does not refer to physical education, but to 'physical development and movement'. Developmental discourses prevail in the 'physical development and movement' section of LTS (2004). Developmental psychology is concerned with determining 'truths' about how children develop (MacNaughton, 2005). Robinson \& Jones Díaz (2006) maintain that Jean Piaget's (1896-1980) work, in which children's development is viewed as 'a biologically predetermined, clearly articulated, linear process towards becoming adults' (p. 6), has dominated understandings of childhood and children's learning. According to Piaget's theory, all children proceed through this process, reaching cognitive developmental stages that correlate with their ages (Robinson \& Jones Díaz, 2006). Developmental assumptions thus influence people's views of what children (and adults) can and cannot do at particular ages (Burrows, 2004). Piaget's model foregrounds the notion of active learning; the child is depicted as a scientist who systematically encounters and solves problems, learning by activity and discovery (Burman, 2008). According to Jones, Hodson \& Napier (2005), Piaget's work 'gave play, particularly in the early years, its distinctive authority as a basis for the evolution of learning' (p. 44). The Scottish Government (2008) stresses that play is essential to ensuring that children will 'have the best start in life and be ready to succeed as adults' (p. 30). 
Burrows (1999) notes that while developmental psychology has tended to be primarily preoccupied with cognitive development, thus paying little attention to the body, a site where the body takes centre stage is within the sub-discipline of motor development. A motor skill development discourse prevails in much physical education research, including in research specifically concerned with young children's physical education (e.g. Derri et al., 2001; Martin, Rudisill \& Hastie, 2009; Zachopoulou, Tsapakidou \& Derri, 2004). Again, motor skill development is often positioned by researchers as a linear, age-related series of stages (Burrows, 1999).

While developmental psychology remains 'a pervasive influence on early childhood pedagogies' (MacNaughton, 2005, p. 25), over the past two decades, research problematising the dominance of developmental discourses has emerged in the fields of both early childhood education (e.g. Ailwood, 2003; Dahlberg, Moss \& Pence, 2007; Fleer, 2006; Robinson \& Jones Díaz, 2006) and - to a lesser extent - physical education (e.g. Burrows, 1999; Burrows \& Wright, 2001). A major reason developmental theories are problematic is their assumption of universality. They therefore provide the benchmark upon which children are compared (Fleer, 2006) and thus have 'normative and exclusionary tendencies' (Burrows \& Wright, 2001, p. 179). Interpretations of 'normal' development vary, however, because developmental milestones are social and cultural constructions, rather than scientific 'truths' (Burrows, 2004). A further reason developmental theories are problematic is that they promote the notion that children are merely adults-in-training (Sorin, 2005). Viewing childhood as purely practice for adulthood (Sorin, 2005) means children are regarded to be 'in a state of becoming rather than being' (Woodrow \& Press, 2007, p. 316, emphasis in original). This dividing boundary between childhood and adulthood positions children as 'innocent...vulnerable 
and in need of protection' (Robinson, 2008, p. 116). Robinson (2008) describes how this can lead to childhood becoming increasingly 'watched' and regulated.

As noted, the previous Scottish preschool curriculum (LTS, 2004) refers to 'physical development and movement', rather than 'physical education'. The 'physical development and movement' section of LTS (2004) draws heavily on developmental discourses. They are evident in, for example, its mentions of play and exploration, and its references to what happens to 'young children' as they 'develop', 'grow' and 'change' (p. 36). My analysis investigates if these discourses also underpin the documentation related to preschool physical education in Curriculum for Excellence. It examines if the change from 'physical development' to 'physical education' has meant that different discourses now underpin the documentation related to this preschool curriculum area, or if developmental discourses still prevail. As such, it examines if the new curriculum appears to have taken account of the critical research discussed above, or if developmental psychology remains a normalised, taken for granted (Fleer, 2005) influence on Scottish preschool physical education.

\section{Investigating preschool physical education discourses in Curriculum for Excellence}

\section{Curriculum for Excellence}

Children in Scotland are entitled to free part-time preschool education from the term after their third birthdays. They usually move to primary school when aged four or five years (The City of Edinburgh Council, 2012). Curriculum for Excellence is a single curriculum for three- to 18 -year-olds. It was launched in 2004 with the publication of $A$ Curriculum for Excellence: The Curriculum Review Group (Scottish Executive, 2004). This document outlines the curriculum's values, purposes and principles, and rationalises its implementation on the grounds that Scotland needs to 'increase the 
economic performance of the nation; reflect its growing diversity; improve health; and reduce poverty' (p. 10). The purposes of Curriculum for Excellence are to enable children and young people to become 'successful learners, confident individuals, responsible citizens and effective contributors to society and at work' (p. 12).

The completed Curriculum for Excellence was published in 2009. At preschools, it replaced A Curriculum Framework for Children 3-5 (LTS, 2004). Curriculum for Excellence claims to be 'less detailed and prescriptive than previous curriculum advice' so as to allow practitioners 'professional space...to meet the varied needs of all children and young people' (LTS, 2009a, p. 3). There are eight curriculum areas (expressive arts, health and wellbeing, languages, mathematics, religious and moral education, sciences, social studies and technologies), each of which has two main guiding texts: 'principles and practice' (which explains the guiding framework, purposes of learning, practitioners' roles and responsibilities, and features of assessment) and 'experiences and outcomes' (which details the specific learning experiences and outcomes children are expected to engage with and achieve). My analysis focuses on the health and wellbeing documentation, as physical education is located within this curriculum area. Health and wellbeing features six strands: mental, emotional, social and physical wellbeing; planning for choices and changes; physical education, physical activity and sport; food and health; substance misuse; and relationships, sexual health and parenthood.

The current paper is primarily concerned with the physical education, physical activity and sport sections of health and wellbeing 'experiences and outcomes' (LTS, 2009c), as this is the section of Curriculum for Excellence that explicitly refers to preschool physical education. In analysing this text, I also make reference to the health and wellbeing 'principles and practice' document (LTS, 2009b) and to three other 
documents, which are significant in relation to preschool physical education in Scotland. Two are papers from 'Building the Curriculum', a series of publications concerned with planning for implementing the curriculum and specifically with involving practitioners 'in professional reflection, debate and rethinking' (Scottish Executive, 2006, p. 1). Both papers were published before the final version of the curriculum, and are concerned with The Contribution of Curriculum Areas (Scottish Executive, 2006) and Active Learning in the Early Years (Scottish Executive, 2007). The third document - Physical Education: Supporting High Quality Physical Education in the Primary School (LTS, 2011) - was published two years after Curriculum for Excellence and accompanies a DVD of the same name. Although the title refers to primary schools, the introduction specifically states that it is also aimed at other educators, including early childhood practitioners.

In order to contextualise my examination of the preschool physical education experiences and outcomes, I first briefly discuss the health and wellbeing 'principles and practice' document. LTS (2009b) is concerned with health and wellbeing in the curriculum generally, so does not specifically refer to preschool education. McEvilly et al. (in press) analyse the section of LTS (2009b) that is specifically concerned with physical education, physical activity and sport, and report that physical activity and health discourses are prevalent. For instance, physical education is characterised as a means to prepare children for 'active', 'healthy', 'fulfilling' lives (p. 6), with words like 'essential', 'should' and 'important' (p. 6) portraying the 'necessity' of physical activity. McEvilly et al. (in press) note that there is an absence of a more sociocultural or critical view of physical education, physical activity and health in LTS (2009b), with practitioners not encouraged to critically engage with claims made. 
These authors also observe that, while 'joy' and 'positive attitudes' are positioned as the 'foundation' (p. 6) for future participation in physically active, healthy lifestyles, there is no mention of motor skills. This is surprising, since previous research (e.g. Thorpe, 2003; Wright, 1997) indicates that physical education is often centred on a motor skill development discourse. Motor skills are referred to, however, in the health and wellbeing 'experiences and outcomes' document (LTS, 2009c), which the current paper examines. While there is no specific mention of motor skill development in LTS (2009b), developmental discourses are evident throughout the document. For example, it proposes that practitioners should 'take account of the stage of development...of each child and young person' (p. 3). Furthermore, although the text acknowledges the significance of social and environmental factors, it states that 'children's capacities to learn are shaped by...their individual development' (p. 4) and that 'progression and development in many aspects of health and wellbeing will depend upon the stage of growth, development and maturity of the individual' (p. 4). These sentences indicate that developmental discourses are likely to feature in the preschool physical education experiences and outcomes (LTS, 2009c).

\section{Methodology}

My analysis features a similar approach to that taken by McEvilly et al. (in press). Like these authors, I follow Wright (2004) by employing a poststructural approach to discourse analysis that involves identifying patterns in the language used in the documents examined. Cox (2010) explains that poststructuralism is a theoretical approach that emerged as a critique of structuralism, which assumes that the 'truth' of 'reality' and the social world can be revealed by collecting and studying data. In contrast, poststructuralism proposes that 'there is no absolute knowledge, no absolute 
reality waiting "out there" to be discovered' (Dahlberg et al., 2007, p. 23). A poststructural perspective thus regards knowledge and its construction as always context-specific and value-laden (Dahlberg et al., 2007). Poststructuralism provokes thinking 'against the grain' (Deegan, 2004, p. 226) of dominant discourses; as such, it is concerned with problematising and disrupting dominant discourses (Yelland \& Kilderry, 2008). Discourses are sets of truths that are (re)produced through power relations and social practices operating in institutions, such as schools, prisons or, in this case, preschools (Foucault, 1973). Discourses, and therefore 'truths' (i.e. knowledge), are thus inscribed in power relations (Dahlberg et al., 2007). Macdonald et al. (2002) note that discourses are productive; they are 'systems of beliefs and values that produce particular social practices and social relations' (p. 143). Competing discourses work to become established as 'normal' and 'natural', leading to the privileging of certain knowledges and practices. Concomitantly, alternative practices and knowledges are excluded (Dahlberg \& Moss, 2005). Discourses, therefore, both privilege and legitimise, and exclude and marginalise (Cassidy, Jones \& Potrac, 2004). Wright (2006) explains that poststructural research in education attempts to 'make visible the ways in which power and knowledge operate to privilege certain practices and forms of subjectivity and to examine the effects on the lives of individuals and groups' (p. 60). Consequently, my analysis involves speculating about the effects of particular discourses on preschool practitioners' and children's practices and subjectivities. A person's subjectivity is his or her 'conscious and unconscious thoughts and emotions...her sense of herself and her ways of understanding her [sic] relation to the world' (Weedon, 1997, p. 32).

Subjectivities are constructed in relation to discourses (O'Flynn, 2010). From a poststructural perspective, subjectivities are viewed as fluid, conflicted and constantly in process (Weedon, 1997). 
I examine the Curriculum for Excellence health and wellbeing 'experiences and outcomes' text - and the related documents - in order to analyse developmental discourses associated with preschool physical education, and to interrogate any ambiguities or contradictions in the documents. I seek to 'disrupt' discourses which may appear to be natural or unquestionable (MacLure, 2003), by raising critical questions about the 'work' they can do in relation to practice. Drawing on guidelines proposed by Carabine (2001) and MacLure (2003), my analysis probes around the following questions: (1) what evidence is there that developmental discourses are circulating in the selected texts? (2) how are knowledge claims related to these developmental discourses established and defended? (3) where are the gaps, silences and inconsistencies? and (4) what are possible consequences regarding practitioners' and children's practices and subjectivities? I subjected the selected documents to 'close reading' (Burrows, 2010, p. 239 ) in order to answer these analytical questions. Repeated reading and re-reading of the texts were required to thoroughly interrogate the workings of the discourses. I do not intend my analysis to be considered as an examination of the 'complete' collection of documentation associated with preschool physical education in Scotland, but as a selected 'mapping of the complex webs of ideas and beliefs which have been ascribed “truth” status' (Burrows, 1999, p. 43). This approach follows Rossi et al. (2009), who suggest that scholars must make choices about 'what it is that needs analyzing' (p. 80) and limit their analysis to particular texts or sections of texts.

\section{Findings: the developmental 'truths' underpinning preschool physical education in Curriculum for Excellence health and wellbeing 'experiences and outcomes'} Immediately illustrating the influence of developmental discourses, the Curriculum for Excellence experiences and outcomes are presented across five levels, which are 
described as 'lines of development which describe progress in learning' (LTS, 2009a, p. 4). The first level - 'early' - concerns children in preschool and the initial year of primary school, 'or later for some' (LTS, 2009a, p. 4). The experiences and outcomes for the physical education, physical activity and sport strand of health and wellbeing are divided into three categories: physical education; physical activity and sport; and physical activity and health. At the early level, there are four experiences and outcomes in the physical education category, one related to physical activity and sport, and two concerning physical activity and health. My primary concern is with the experiences and outcomes specifically categorised under 'physical education'.

The introduction to the physical education experiences and outcomes draws on a number of discourses. As in the 'principles and practice' text, discourses related to health and physical activity are present. Of significance to the current paper, however, is the presence of developmental discourses. They are evident in the concern with motor skill development, which is positioned as the 'key' to lifelong physical activity:

Physical education provides learners with a platform from which they can build physical competences, improve aspects of fitness, and develop personal and interpersonal skills and attributes. It enables learners to develop the concepts and skills necessary for participation in a wide range of physical activity, sport, dance and outdoor learning, and enhances their physical wellbeing in preparation for leading a fulfilling, active and healthy lifestyle. (LTS, 2009c, p. 5)

The strong verbs ('provides', 'enables', 'enhances') position the development of motor skills in order to lead an active, healthy life as the goal of physical education. Similarly, 
LTS (2011), citing the Association for Physical Education (AfPE) (2008), describes physical education as 'the foundation for a lifelong engagement in physical activity and sport' (p. 4). It states that, in physical education, 'children learn and build a movement vocabulary and develop an understanding of what a quality action looks like and feels like' (p. 15). Furthermore, of the four early level experiences and outcomes in the physical education category, three are specifically concerned with movement skills and concepts. The four experiences and outcomes are:

I am learning to move my body well, exploring how to manage and control it and finding out how to use and share space. (LTS, 2009c, p. 5)

I am developing my movement skills through practice and energetic play. (LTS, 2009c, p. 5)

I am aware of my own and others' needs and feelings, especially when taking turns and sharing resources. I recognise the need to follow rules. (LTS, 2009c, p. 6)

By exploring and observing movement, I can describe what I have learned about it. (LTS, 2009c, p. 6)

These statements focus strongly on individual development and learning, although the third one also concerns children's relationships with other people. The references to 'exploring', 'finding out' and 'play' place emphasis on active learning. LTS (2011) explicitly states that in physical education, 'children should be active learners' (p. 9). As 
noted earlier, Piaget's model of cognitive development foregrounds the concept of active learning. The above statements therefore clearly illustrate the influence of developmental discourses on the curriculum. Indeed, the fact that one of the 'Building the Curriculum' documents is entitled Active Learning in the Early Years (Scottish Executive, 2007) shows how pervasive developmental discourses are in early childhood education in Scotland. Scottish Executive (2007) links active learning to concepts including play, exploration, child-centredness and fun. Under the heading 'Research Background', it states:

Research indicates that developmentally appropriate practice is most conducive to effective learning. For example, it suggests that there is no long-term advantage to children when there is an over-emphasis on systematic teaching before 6 or 7 years of age. (p. 6)

The wording of this excerpt indicates that, while a certain amount of 'teaching' may be acceptable in early childhood education, children should not be taught in a certain way until they are a particular age. Development and learning appear to be positioned as separate entities; development happens automatically, in relation to age, while learning is dependent on environment and 'developmentally appropriate' experiences. The specific reference to age provides evidence of the way developmental theories assume universality. The reference to 'research' strengthens the argument that developmentally appropriate practice is 'imperative', by seemingly providing 'proof' and legitimacy to the claims made. Although practitioners are referred to a review of literature related to the 'benefits' of active learning, the specific research that makes the above claims is not 
directly referenced. Therefore, practitioners are not encouraged to critically engage with the claims; they are expected to accept what the documentation says as 'truth'.

Developmentally appropriate practice is also uncritically promoted in LTS (2011), which, citing AfPE (2008), proposes that physical education 'should be developmentally appropriate to help [children] acquire psychomotor skills, cognitive understanding, social skills and the emotional learning they need to lead a physically active life' (p. 4). This document again positions developmentally appropriate practice as 'imperative' and explicitly assumes that practitioners have detailed knowledge of it, claiming that they are:

...best placed to offer developmentally appropriate PE because they know their children very well and have detailed understanding of the developing child and how this development influences their engagement and learning in PE. (p. 4)

Not only is it taken for granted in this excerpt that developmentally appropriate practice is necessary for 'high quality physical education' (LTS, 2011, p. 4), it is taken for granted that practitioners have detailed knowledge of it and will agree with this view. There is again no sign of a more critical engagement with the notion of developmentally appropriate practice, or even a recognition that some practitioners may take a more critical view of it; as in Scottish Executive (2007), it is simply presented as 'truth'. Furthermore, both this excerpt and the statements from LTS (2009c) presented above appear to assume that practitioners have a high level of expertise in relation to teaching physical education. I noted earlier that Curriculum for Excellence claims to be less prescriptive than previous Scottish curricular documentation, so the statements may have been constructed with this aspiration in mind. However, another interpretation is 
that they are quite vague (Priestley \& Humes, 2010) and thus may prove problematic for practitioners with little knowledge or experience of physical education. For instance, no explanation is given of what moving 'well' might involve or look like. Similarly, there is no description or explanation of the 'movement skills' children are 'developing', although the reference to 'space' indicates that this is a movement concept that should be focused on.

The second of the four experiences and outcomes presented above refers to 'energetic play'. This concept is also mentioned in the second category of experiences and outcomes in the physical education, physical activity and sport strand of health and wellbeing, which concerns physical activity and sport. The early level experience and outcome for this category is:

I am enjoying daily opportunities to participate in different kinds of energetic play, both outdoors and indoors. (LTS, 2009c, p. 7)

Discourses related to physical activity and play come together in the notion of 'energetic play'. This indicates that the curriculum positions play - rather than more adult-led activities - as an appropriate means of increasing children's physical activity levels. This aligns with the contention above that young children gain no benefit from 'systematic teaching', as it is not 'developmentally appropriate' (Scottish Executive, 2007, p. 6).

\section{Discussion}

As noted earlier, there is a wealth of literature that problematises the dominance of developmental discourses in early childhood education, and a smaller amount of similar 
scholarship in physical education. However, my analysis shows that developmental discourses are prevalent throughout the Curriculum for Excellence documentation related to preschool physical education. This indicates that, despite the criticisms of developmental discourses in some contemporary early childhood (and physical education) literature, they have retained their position as central to preschool physical education in Scotland. My concerns lie with the ways in which these discourses may be taken up and deployed within preschool educational establishments.

There is no recognition in the texts analysed that developmental discourses provide the benchmark upon which children are compared (Fleer, 2006) and consequently can be 'normative and exclusionary' (Burrows \& Wright, 2001, p. 179). I wonder, for instance, if the emphasis on motor skill development could lead to the classification and exclusion (Gore, 1995) of some preschoolers because of perceived motor skill deficiencies. Exclusion is the opposite of normalisation; it involves 'defining...the pathological' (Gore, 1995, p. 173). Gore (1995) defines classification as a technique of power that entails 'differentiating groups or individuals from one another, classifying them, classifying oneself' (p. 174). Following Burrows and Wright (2001), I recognise that acquiring certain skills (e.g. particular locomotor, stability and manipulation skills) will be a lifelong challenge for some children, and question if specifically associating these skills with young children pathologises those who do not accomplish them when developmental 'truths' say they should.

The 'experiences and outcomes' document positions motor skill development as the 'key' to lifelong physical activity and health. The claim that children 'need' to develop particular skills in order to 'access' sports and other physical activities when they are older is regularly cited throughout the literature as a justification for physical education (e.g. Derri et al., 2001; Jess, Dewar \& Fraser, 2004). I suggest, however, that 
the relationship between motor skill development in childhood and physical activity participation in adulthood is likely to be more tenuous than is often implied; physical activity participation in adulthood is likely to be affected by many more structural and environmental factors than skill level alone. As such, characterising motor skill development and physical activity participation as linked in a linear cause-and-effect manner obscures the multitude of factors that may impact on physical activity participation in adulthood and ignores the daily realities of many people's lives (Gard \& Wright, 2005).

As noted, the experiences and outcomes discussed focus strongly on individual development and learning. Indeed, this could be said of all the experiences and outcomes in the curriculum, since they are written in the first person. I argue that, while writing in this way is intended to place the learner at the centre of the curriculum (Priestley \& Humes, 2010), it positions learning as a primarily individual endeavour. This has the effect of ignoring the richness and complexity of children's lives and experiences (Dahlberg et al., 2007). Moreover, I align with Priestley \& Humes’s (2010) assertion that there is a certain degree of artificiality in the strategy, because of the use of language the intended learners are unlikely to use. For instance, while wary of proceeding on the basis of developmental assumptions regarding what they 'should' be able to do, I find it difficult to imagine young children talking about 'developing...movement skills' or 'observing movement', because it seems unlikely that practitioners would use such terms with them. In this way, writing the experiences and outcomes in the first person seems to be 'an artifice devised by the planners rather than a true reflection of the learning process' (Priestley \& Humes, 2010, p. 353).

Furthermore, although the references to concepts such as 'finding out', 'play' and 'exploring' (LTS, 2009c, p. 6) throughout the selected documentation may portray 
the idea that children will be 'free' from adult control, all of their activities will be watched, regulated and monitored by adults; children will not necessarily have the freedom the aforementioned words may imply. In addition, the uncritical privileging of developmental discourses and related concepts (e.g. play, child-centredness) ignores the idea that they may be problematic in practice (Burman, 2008). Such criticisms are silenced in the documents analysed due the strength of the developmental discourses underpinning them.

\section{Conclusion}

My aim has been to interrogate the developmental discourses associated with preschool physical education in Scotland's Curriculum for Excellence. In investigating my four analytical questions, I have presented evidence that, despite the change from 'physical development and movement' to 'physical education', developmental discourses still prevail. I have shown how knowledge claims related to these discourses are established and defended (e.g. through the mention of 'research') and highlighted silences (e.g. the lack of critical engagement with the notion of developmentally appropriate practice). I have consequently speculated about potential effects of these discourses on practitioners and children.

While I have critically analysed particular discourses, it has not been my intention to imply that these discourses should be abandoned. Following Baker (1999), I recognise that developmental psychology has been beneficial in terms of, for example, its focus on children's health, but my concerns centre around the 'more dangerous and less good implications of its emergence' (p. 820). As such, I wish to highlight potentially negative consequences of uncritical reliance on developmental discourses. I hope this paper has shown how important it is for preschool practitioners - as well as 
researchers and policy-makers - to critically engage with the curriculum and reflect on the potential workings and effects of discourses and related practices that they may privilege and take for granted. I suggest that future research should examine the ways in which the developmental discourses examined in my analysis are taken up and negotiated by practitioners and children in Scottish preschool physical education contexts. Interrogating the ways in which preschool practitioners and children interpret the practices and messages associated with these discourses is vital in order to lay bare their effects on young children.

\section{Acknowledgements}

I would like to thank Dr. Martine Verheul, Dr. Matthew Atencio and Dr. Mike Jess for their support and guidance. I would also like to thank the anonymous reviewers for their constructive feedback. 


\section{References}

Ailwood, J. (2003) Governing Early Childhood Education Through Play, Contemporary Issues in Early Childhood, 4(3), 286-299.

Baker, B. (1999) The Dangerous and the Good? Developmentalism, Progress, and Public Schooling, American Educational Research Journal, 36(4), 797-834.

Burman, E. (2008) Deconstructing Developmental Psychology. Hove, East Sussex: Routledge.

Burrows, L. (1999) Developmental Discourses in School Physical Education. Unpublished $\mathrm{PhD}$ thesis, University of Wollongong.

Burrows, L. (2004) 'Developing' Athletes, in T. Cassidy, R. Jones \& P. Potrac Understanding Sports Coaching: the social, cultural and pedagogical foundations of coaching practice. Abingdon, Oxon: Routledge.

Burrows, L. (2010) 'Kiwi Kids are Weet-Bix ${ }^{\mathrm{TM}}$ Kids' - Body Matters in Childhood, Sport, Education and Society, 15(2), 235-251.

Burrows, L. \& Wright, J. (2001) Developing Children in New Zealand School Physical Education, Sport, Education and Society, 6(2), 165-182.

Cannella, G.S. (2008) Reconceptualizing the Field (of Early Care and Education): if 'western' child development is a problem, then what do we do?, in N. Yelland (Ed.) Critical Issues in Early Childhood Education. Maidenhead, Berkshire: Open University Press.

Carabine, J. (2001) Unmarried motherhood 1830-1990: a genealogical analysis, in M. Wetherell, S. Taylor \& S.J. Yates (Eds.) Discourse as Data: a guide for analysis. London: Sage Publications Ltd.

Cassidy, T., Jones, R. \& Potrac, P. (2004) Understanding Sports Coaching: the social, cultural and pedagogical foundations of coaching practice. Abingdon, Oxon: Routledge.

Cox, B.D. (2010) Issues of Power in a History of Women's Football in New Zealand: a Foucauldian genealogy. Unpublished $\mathrm{PhD}$ thesis, University of Waikato.

Dahlberg, G. \& Moss, P. (2005) Ethics and Politics in Early Childhood Education. Abingdon, Oxfordshire: RoutledgeFalmer.

Dahlberg, G., Moss, P. \& Pence, A. (2007) Beyond Quality in Early Childhood Education and Care: languages of evaluation. Abingdon, Oxon: Routledge.

Deegan, J. (2004) 'Intentionally or otherwise': children and diversity in statutory and policy discourses in Ireland, in J. Deegan, D. Devine \& A. Lodge (Eds.) Primary Voices: equality, diversity and childhood in Irish primary schools. Dublin: Institute of Public Administration. 
Derri, V., Tsapakidou, A., Zachopoulou, E. \& Kioumourtzoglou, E. (2001) Effect of a Music and Movement Programme on Development of Locomotor Skills by Children 4 to 6 Years of Age, Physical Education and Sport Pedagogy, 6(2), 1625.

Fleer, M. (2005) Developmental Fossils - Unearthing the Artefacts of Early Childhood Education: the reification of 'child development', Australian Journal of Early Childhood, 30(2), 2-7.

Fleer, M. (2006) The Cultural Construction of Child Development: creating institutional and cultural intersubjectivity, International Journal of Early Years Education, $14(2), 127-140$.

Foucault, M. (1973) The Birth of the Clinic: an archaeology of medical perception. London: Tavistock.

Gard, M. \& Wright, J. (2005) The Obesity Epidemic: science, morality and ideology. Abingdon, Oxon: Routledge.

Gore, J.M. (1995) On the Continuity of Power Relations in Pedagogy, International Studies in Sociology of Education, 5(2), 165-188.

Jess, M., Dewar, K. \& Fraser, G. (2004) Basic Moves: developing a foundation for lifelong physical activity, The British Journal of Teaching Physical Education, 35(2), 24-27.

Jones, L., Hodson, E. \& Napier, N. (2005) The Politics of Play, in L. Jones, R. Holmes \& J. Powell (Eds.) Early Childhood Studies: a multiprofessional perspective. Maidenhead, Berkshire: Open University Press.

Kirk, D. (2005) Physical Education, Youth Sport and Lifelong Participation: the importance of early learning experiences, European Physical Education Review, 11(3), 239-255.

LTS (2004) A Curriculum Framework for Children 3-5.

http://www.ltscotland.org.uk/Images/CF3to5 tcm4-115469.pdf

LTS (2009a) Curriculum for Excellence.

http://www.ltscotland.org.uk/Images/all experiences outcomes tcm4539562.pdf

LTS (2009b) Curriculum for Excellence: health and wellbeing, principles and practice. http://www.ltscotland.org.uk/Images/health_wellbeing_principles practice tcm 4-540107.pdf

LTS (2009c) Curriculum for Excellence: health and wellbeing, experiences and outcomes.

http://www.ltscotland.org.uk/Images/health_wellbeing_experiences_outcomes t cm4-540031.pdf 
LTS (2011) Physical Education: supporting high quality physical education in the primary school.

http://www.ltscotland.org.uk/Images/pe_dvd_booklet_tcm4-651368.pdf

Macdonald, D., Kirk, D., Metzler, M., Nilges, L.M., Schempp, P. \& Wright, J. (2002) It's All Very Well, in Theory: theoretical perspectives and their applications in contemporary pedagogical research, Quest, 54(2), 133-156.

MacLure, M. (2003) Discourse in Educational and Social Research. Buckingham: Open University Press.

MacNaughton, G. (2005) Doing Foucault in Early Childhood Studies: applying poststructural ideas. Abingdon, Oxon: Routledge.

Martin, E.H., Rudisill, M.E. \& Hastie, P.A. (2009) Motivational Climate and Fundamental Motor Skill Performance in a Naturalistic Physical Education Setting, Physical Education and Sport Pedagogy, 14(3), 227-240.

McEvilly, N., Verheul, M., Atencio, M. \& Jess, M. (in press) Physical Education for Health and Wellbeing: a discourse analysis of Scottish physical education curricular documentation, Discourse: Studies in the Cultural Politics of Education.

O’Flynn, G. (2010) The Business of 'Bettering' Students' Lives: physical and health education and the production of social class subjectivities, Sport, Education and Society, 15(4), 431-445.

Priestley, M. \& Humes, W. (2010) The Development of Scotland's Curriculum for Excellence: amnesia and déjà vu, Oxford Review of Education, 36(3), 345-361.

Robinson, K.H. (2008) In the Name of 'Childhood Innocence': a discursive exploration of the moral panic associated with childhood and sexuality, Cultural Studies Review, 14(2), 113-129.

Robinson, K.H. \& Jones Díaz, C. (2006) Diversity and Difference in Early Childhood Education. Maidenhead, Berkshire: Open University Press.

Rønholt, H. (2002) 'It's Only the Sissies...': analysis of teaching and learning processes in physical education: a contribution to the hidden curriculum, Sport, Education and Society, 7(1), 25-36.

Rossi, T., Tinning, R., McCuaig, L., Sirna, K. \& Hunter, L. (2009) With the Best of Intentions: a critical discourse analysis of physical education curriculum materials, Journal of Teaching in Physical Education, 28(1), 75-89.

Scottish Executive (2004) A Curriculum for Excellence: the curriculum review group. Edinburgh: Scottish Executive. 
Scottish Executive (2006) A Curriculum for Excellence: building the curriculum 1: the contribution of curriculum areas.

http://www.ltscotland.org.uk/Images/building_curriculum1_tcm4-383389.pdf

Scottish Executive (2007) A Curriculum for Excellence: building the curriculum 2:

active learning in the early years.

http://www.ltscotland.org.uk/curriculumforexcellence/images/Building\%20the \%20Curriculum\%202_tcm4-408069.pdf

Scottish Government (2008) The Early Years Framework Part II. http://www.scotland.gov.uk/Resource/Doc/257007/0076310.pdf

Sorin, R. (2005) Changing Images of Childhood - Reconceptualising Early Childhood Practice, International Journal of Transitions in Childhood, 1, 12-21.

Stephen, C. (2006) Insight 28: early years education: perspectives from a review of the international literature.

http://www.scotland.gov.uk/Resource/Doc/90566/0021792.pdf

The City of Edinburgh Council (2012) Pre-school nursery education. http://www.edinburgh.gov.uk/info/851/nurseries_and playgroups/566/preschool_nursery_education/1

Thorpe, S. (2003) Crisis Discourse in Physical Education and the Laugh of Michel Foucault, Sport, Education and Society, 8(2), 131-151.

Weedon, C. (1997) Feminist Practice and Poststructuralist Theory. Oxford: Blackwell Publishers Ltd.

Woodrow, C. \& Press, F. (2007) (Re)Positioning the Child in the Policy/Politics of Early Childhood, Educational Philosophy and Theory, 39(3), 312-325.

Wright, J. (1997) The Construction of Gendered Contexts in Single Sex and Coeducational Physical Education Lessons, Sport, Education and Society, 2(1), 5572 .

Wright, J. (2004) Post-structural Methodologies: the body, schooling and health, in J. Evans, B. Davies \& J. Wright (Eds.) Body Knowledge and Control: studies in the sociology of physical education and health. London: Routledge.

Wright, J. (2006) Physical Education Research from Postmodern, Poststructural and Postcolonial Perspectives, in D. Kirk, D. Macdonald \& M. O’Sullivan (Eds.) The Handbook of Physical Education. London: SAGE Publications Ltd.

Yelland, N. \& Kilderry, A. (2008) Postmodernism, Passion and Potential for Future Childhoods, in N. Yelland (Ed.) Critical Issues in Early Childhood Education. Maidenhead, Berkshire: Open University Press. 
Zachopoulou, E., Tsapakidou, A. \& Derri, V. (2004) The Effects of a Developmentally Appropriate Music and Movement Program on Motor Performance, Early Childhood Research Quarterly, 19, 631-642. 